\title{
Recommendations for the administration of influenza vaccine in children allergic to egg
}

\author{
M Erlewyn-Lajeunesse, 1 N Brathwaite, ${ }^{2}$ J S A Lucas, ${ }^{13}$ J 0 Warner ${ }^{4}$
}

$\overline{1 S o u t h a m p t o n ~ U n i v e r s i t y ~ H o s p i t a l s ~}$ NHS Trust, Southampton

${ }^{2}$ King's College Hospital, London

3nfection Inflammation and

Immunology, School of Medicine,

University of Southampton,

Southampton

4 Imperial College and Imperial

College Healthcare NHS Trust,

London

Correspondence to:

M Lajeunesse, The Children's

Allergy Clinic, Southampton

University Hospitals NHS Trust,

Southampton S016 6YD

mich.lajeunesse@soton.ac.uk

Cite this as: $B M / 2009 ; 339: b 3680$ doi: 10.1136/bmj.b3680
Egg allergy affects about 2.6\% of preschool children by 3 years of age, and influenza immunisation using egg based vaccines has been classified as a "relative contraindication" (prescribe with extra caution) in this patient group. ${ }^{1}$ Until now the numbers of children with egg allergy requiring immunisation has been low, but this may change with the potential for a mass immunisation campaign. This article reviews the literature on the safety of flu vaccines and provides guidelines for the administration of these vaccines to children with egg allergy. Although egg-free flu vaccines are expected to be available for this season, the provision of sufficient amounts of this vaccine cannot be guaranteed at the time of writing, and a pragmatic strategy for the safe immunisation of children with egg allergy is required.

\section{Sources and selection criteria}

We identified articles using PubMed and the search terms "influenza" and "egg allergy". We identified further references within relevant papers. We found two randomised clinical trials, but most evidence comes from small case series.

\section{What vaccines are available?}

This season two varieties of flu vaccine will be available: a pandemic $\mathrm{A} / \mathrm{H} 1 \mathrm{~N} 1$ strain and the normal trivalent seasonal flu vaccine that will contain an $\mathrm{A} / \mathrm{H} 1 \mathrm{~N} 1$ virus

\section{SUMMARY POINTS \\ Egg-free, mammalian culture based flu vaccines should be given preferentially to individuals allergic to egg \\ If an egg-free vaccine is not available, only vaccines with a stated maximum egg content $<1.2 \mu \mathrm{g} / \mathrm{ml}(0.6 \mu \mathrm{g}$ per dose $)$ should be used in individuals allergic to egg \\ If egg based vaccine is administered to individuals with egg allergy, this should be done in a centre experienced in the management of anaphylaxis \\ A single dose protocol is recommended for those with less severe egg allergy \\ A two dose, split protocol can be used in those with anaphylaxis to egg or those with moderate or uncontrolled asthma}

but will not protect against the pandemic strain. There is an egg-free flu vaccine for seasonal immunisation, and it is anticipated that there will be one available for the pandemic strain (table 1). These egg-free vaccines are produced using new viral culture techniques in a mammalian cell line. ${ }^{23}$ Inactivated, split flu virus, split virion, subunit, or surface antigen flu vaccines are grown in hens' eggs and contain residual allergenic egg white proteins. Some but not all of last season's flu vaccines (2008) reported maximum egg protein content above the proposed safety cut-off of $1.2 \mu \mathrm{g} / \mathrm{ml}$, with levels up to $2 \mu \mathrm{g} / \mathrm{ml}$. Virosomal vaccines are highly purified, and although still grown in egg cultures, often have much less residual egg protein. ${ }^{4}$

\section{What is the evidence for the current contraindications?} According to the Department of Health guidance on immunisation in the Green Book and manufacturer's product characteristics, flu immunisation is contraindicated by a confirmed anaphylaxis to a previous dose of the vaccine, to any component of the vaccine, or to egg products. ${ }^{5}$ Despite the use of anaphylaxis as a severity cut-off, flu vaccines have been used cautiously in individuals with egg allergy. We will look at the evidence for each of these contraindications in turn.

Anaphylaxis as an adverse event after immunisation is a rare event at about one in a million doses. ${ }^{67}$ There

Table 1 | Brands of influenza vaccine available in the UK for the autumn 2009 immunisation campaign*

\begin{tabular}{lccc}
$\begin{array}{l}\text { Influenza } \\
\text { vaccine type }\end{array}$ & $\begin{array}{c}\text { Pandemic } \\
\text { A/H1N1 }\end{array}$ & $\begin{array}{c}\text { Seasonal } \\
2009\end{array}$ & $\begin{array}{c}\text { Vaccine choice for } \\
\text { individuals with egg allergy }\end{array}$ \\
\hline Virosome & $\begin{array}{c}\text { Celvapan } \\
\text { (Baxter) }\end{array}$ & $\begin{array}{c}\text { Optaflu } \\
\text { (Novartis) }\end{array}$ & First \\
& $\begin{array}{c}\text { None } \\
\text { available }\end{array}$ & $\begin{array}{c}\text { Viroflu (Sanofi } \\
\text { Pasteur MSD) }\end{array}$ & Second \\
\hline Standardt‡ & $\begin{array}{c}\text { Pandemrix } \\
\text { (GSK) }\end{array}$ & $\begin{array}{c}\text { All other } \\
\text { brandst }\end{array}$ & Third
\end{tabular}

*These brands will change between seasons, as will the egg content of standard vaccines.

†Standard vaccine types containing hens' egg protein are described as inactivated, split flu virus, split virion, subunit, or surface antigen. $\ddagger$ Brands that contain hens' egg protein and are used in individuals with egg allergy should have a stated ovalbumin content preferably $<1.2 \mu \mathrm{g} / \mathrm{ml}$ or $0.6 \mu \mathrm{g} /$ dose to be in keeping with safety data (see text). 


\begin{tabular}{|c|c|c|c|c|c|}
\hline & $\begin{array}{l}\text { Influenza vaccine } \\
\text { diagnostics }\end{array}$ & $\begin{array}{l}\text { Positive vaccine } \\
\text { diagnostics }\end{array}$ & $\begin{array}{l}\text { Previous anaphylaxis } \\
\text { to egg }\end{array}$ & $\begin{array}{l}\text { Vaccine administration } \\
\text { schedule }\end{array}$ & $\begin{array}{l}\text { Immediate adverse } \\
\text { events }\end{array}$ \\
\hline Davies and Pepys ${ }^{15}$ & SPT neat & $7 / 22$ & Not stated & Not given & $\mathrm{Nil}^{\star}$ \\
\hline \multirow[t]{2}{*}{ Bierman et al ${ }^{11}$} & SPT neat & $0 / 142 \dagger$ & $1 / 142$ & 2 single doses, 4 weeks apart & $\mathrm{Nil}$ \\
\hline & IDT 1:100 & $12 / 142$ & 12/142 "severe" & Not given if IDT positive & Nil \\
\hline Miller et al ${ }^{16}$ & IDT 1:100 & $5 / 42$ & 3/42 "severe" & Not given & Nil \\
\hline Murphy and Strunk ${ }^{17}$ & $\begin{array}{l}\text { SPT } 1: 10 \\
\text { IDT } 1: 100\end{array}$ & 0/6 (SPT) 6/6 (IDT) & Not stated & Six doses, graded $\neq$ & $\begin{array}{l}\text { All had asthma, } 1 \text { wheezed } 20 \\
\text { min after second dose }\end{array}$ \\
\hline Anolik et al ${ }^{18}$ & IDT 1:100 & $\begin{array}{l}8 / 8 \text { (egg allergy group), } \\
5 / 8 \text { (controls) }\end{array}$ & Not stated & Six doses, graded $\ddagger$ & Nil \\
\hline James et al ${ }^{19}$ & SPT neat & $\begin{array}{l}\text { 4/83 (egg allergy group), } \\
1 / 124 \text { (controls) }\end{array}$ & $27 / 83$ & Split dose§ & Nil \\
\hline Esposito et al ${ }^{20}$ & SPT neat & $\begin{array}{l}\text { 0/44 (egg allergy group), } \\
\text { 0/44 (controls) }\end{array}$ & $11 / 44$ & Single dose of virosmal vaccine & Nil \\
\hline
\end{tabular}

ITD= intradermal dilutional testing

SPT=skin prick testing.

*Two (of seven) reported adverse reactions to a previous dose of influenza vaccine.

tTwo children allergic to eggs developed a positive IDT result before the second dose of vaccine, which was then withheld.

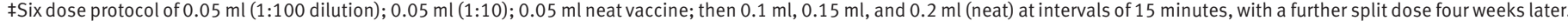

$\S$ Two dose, split protocol of $1 / 10$ th, followed by $9 / 10$ th 30 minutes later using a vaccine with $<1.2 \mu \mathrm{g} / \mathrm{ml}$ ovalbumin content.

\section{Common false} contraindications to influenza immunisation The following are not contraindications to immunisation with flu vaccine:

- A history of egg allergy but now able to eat eggs without reaction

- A family history of egg allergy-in a sibling or other family member

- A family history of reaction to flu or any other vaccine is a paucity of published data on the risk of allergic reaction to flu vaccine. ${ }^{8}$ A large population based study in the United States in 1976 found 11 episodes of non-fatal anaphylaxis in 48 million doses. ${ }^{9}$ None of the patients with an anaphylaxis to the flu vaccine reported a history of egg allergy.

Excipients in the vaccine can act as allergens in sensitised individuals, as seen with gelatin in the measles, mumps, and rubella vaccine (MMR vaccine) during the 1990 s. ${ }^{10}$ Common residues of production found in flu vaccines include the stabiliser polysorbate 80 and antibiotics such as gentamicin, neomycin, kanamycin, and polymyxin $\mathrm{B}$. There are no reports of anaphylaxis to flu vaccine caused by sensitivity to these agents.

All reported cases of anaphylaxis after flu immunisation in individuals with egg allergy occurred over 20 years ago. At least one case of fatal anaphylaxis after influenza vaccine occurred in a child with egg allergy during the 1970s. ${ }^{11}$ In 1946 Ratner and Untracht described two cases of adult anaphylaxis related to flu vaccine and egg intolerance from their literature review; they also documented two children who had immediate allergic reactions to full strength intradermal testing with flu vaccine. ${ }^{12}$ The egg content of the vaccines causing these reactions was likely to have been much higher than those available today. The ovalbumin content of flu vaccines has been shown to change by manufacturer and by year. ${ }^{13}{ }^{14}$ More recently, manufacturers have published the maximum egg content of their vaccines in their "summary of product characteristics," which helps to make an assessment of their safety in egg allergy.

\section{Can influenza vaccine be given safely in egg allergy?}

Several reports have been published of the safe immunisation of individuals allergic to egg with flu vaccines containing egg (table 2). Initial case series excluded all who had a positive skin prick or intradermal testing to the flu vaccine. ${ }^{111516}$ Later case series showed that positive skin and intradermal tests to the vaccine did not predict reactivity, and that individuals with an anaphylaxis to egg have been immunised safely using a split dose protocol (six dose or two dose). ${ }^{17-19}$
The most convincing evidence comes from a prospective multicentre controlled trial using a split dose protocol. ${ }^{19}$ Flu vaccine was administered in two doses 30 minutes apart; the first dose was $1 / 10$ th $(0.05 \mathrm{ml})$ and the second dose $9 / 10$ th $(0.45 \mathrm{ml})$ of the recommended dose. The content of egg protein in the vaccines used in this trial was known to be less than 1.2 $\mu \mathrm{g} / \mathrm{ml}(0.6 \mu \mathrm{g}$ per $0.5 \mathrm{ml}$ dose $)$. Eighty three individuals with confirmed egg allergy were recruited, of whom 27 had a convincing history of anaphylaxis to egg. The 124 control participants without egg allergy received a standard single dose of the vaccine. All patients with egg allergy tolerated the split dose vaccination protocol without any significant allergic reaction. A controlled study also showed that a virosomal vaccine with a single dose protocol was safe in those with egg allergy. ${ }^{20}$

Although these studies have cautiously established the safety of flu vaccines in a small sample of individuals with egg allergy, the studies are too small to establish the risk of anaphylaxis; however, all subjects tolerated a cumulative full dose of vaccine.

\section{What do current guidelines say?}

The current guidance has interpreted these data in different ways. ${ }^{14} 2122$ The American Academy of Paediatrics' Red Book has recommended a graded, five injection protocol after an initial $0.05 \mathrm{ml}$ of 1:10 vaccine dilution, in a setting with full resuscitation facilities. ${ }^{22}$ Two variations of a two dose, split protocol have also been recommended: one using a 1:100 intradermal test before dosing, whereas the other forgoes diagnostics but excludes those with anaphylaxis to egg. ${ }^{1421}$ Neither of these guidelines incorporates the evidence for the safe administration of vaccine either to those with anaphylaxis to egg or to those apparently sensitised to the vaccine (with a positive intradermal test) using a two dose split protocol. ${ }^{19}$ The British Society of Allergy and Clinical Immunology has recently ratified guidelines based on our advice to members of the Paediatric Allergy Group for the 2008 flu season, which form the basis of our recommendations. ${ }^{23}$ 


\section{What should we do?}

Given the likelihood of mass immunisation to flu, including preschool children, a pragmatic approach is essential to ensure that individuals with egg allergy are protected, both from the disease and from the risks of immunisation.

\section{Is the child allergic to egg?}

Egg allergy is easily diagnosed from a clear history of immediate allergic reaction to egg or to a food containing egg. All children with immediate reactions to egg, including those with localised rashes on exposure, should have skin prick testing or estimation of specific $\mathrm{IgE}$ to confirm the diagnosis. Specialist advice may be needed if the diagnosis remains uncertain. We have outlined clinical decision steps in the algorithm (figure).

Anaphylaxis to chicken meat, feathers, and dander

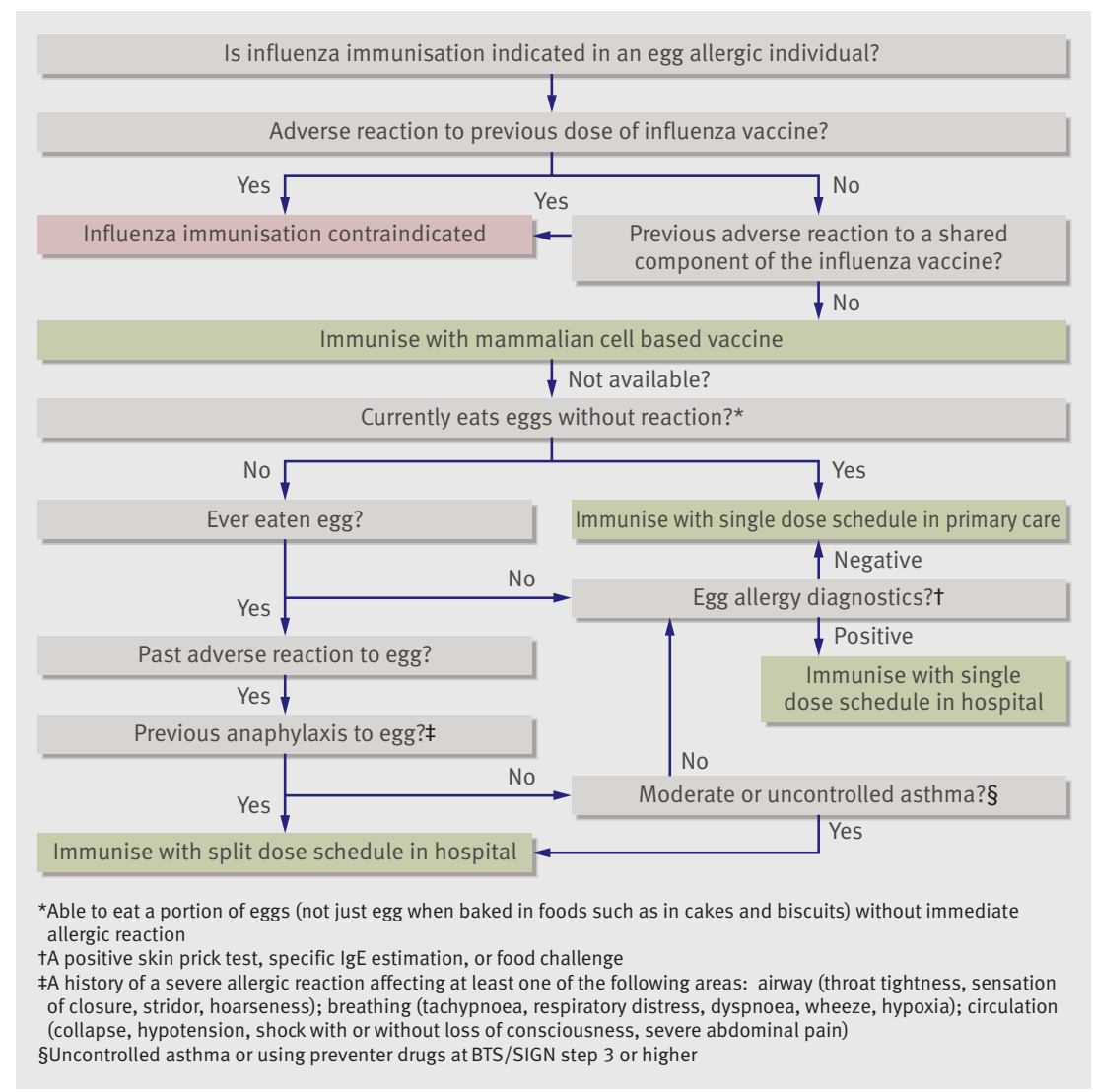

Algorithm for the immunisation of individuals allergic to egg with influenza vaccine

\begin{tabular}{lll}
\hline Table $\mathbf{3}$ | Immunisation with an egg containing vaccine \\
Lower risk & $\begin{array}{l}\text { Worst previous reaction to egg } \\
\text { Previous mild gastrointestinal or } \\
\text { dermatological reaction to egg and positive } \\
\text { diagnostics; orpositive diagnostics but never } \\
\text { knowingly exposed to egg }\end{array}$ & $\begin{array}{l}\text { Vaccine protocol } \\
\text { of a virosomal vaccine or a vaccine with low egg } \\
\text { content }(<1.2 \mu \mathrm{g} / \mathrm{ml}) \text { if virosomal not available }\end{array}$ \\
\hline Higher risk & $\begin{array}{l}\text { Previous respiratory or cardiovascular } \\
\text { reaction to egg, and positive diagnostics; } \\
\text { or“lower risk” individual with uncontrolled } \\
\text { asthma treated at BTS/SIGN step 3 or higher }\end{array}$ & $\begin{array}{l}\text { Two dose, split protocol of } 0.05 \mathrm{ml} \\
\text { intramuscularly, followed } 30 \text { minutes later by } 0.45 \\
\text { ml of a virosomal vaccine or a vaccine with low egg } \\
\text { content }(<1.2 \mu \mathrm{g} / \mathrm{ml}) \text { if virosomal not available }\end{array}$
\end{tabular}

This table considers the approach if an egg-free vaccine is not available. Mild gastrointestinal and dermatological reactions include urticaria, angio-oedema, and vomiting. Anaphylaxis is characterised by symptoms involving the airway and respiratory tract, such as pharyngeal oedema, stridor, respiratory distress, and wheeze. Cardiovascular complications include circulatory shock, hypotension, severe abdominal pain, or collapse. Positive diagnostics are skin prick and specific IgE tests to egg protein. has been reported as a contraindication to flu vaccine by some manufacturers. Although such allergies are rare, no cases of anaphylaxis to flu immunisation in such individuals have been reported. These rare allergies remain a theoretical risk and in the absence of any firm clinical data should be treated in the same way as egg allergy.

Many children outgrow their egg allergy in the first few years of life. If a child can eat lightly cooked egg (such as a spoonful of scrambled egg) without reaction then they are no longer allergic. We do not recommend testing children allergic to egg by a trial at home of food containing egg because of the risk of an unsupervised allergic reaction. A specialist should assess a child's current sensitivity. Children tolerating egg in baked products (such as cake) but not boiled or scrambled egg are still potentially at risk of severe reaction.

\section{Which vaccine should be used?}

We recommend that all individuals with egg allergy should be immunised with a mammalian culture based flu vaccine (table 1). If a mammalian cell culture vaccine is not available then we recommend using a virosomal vaccine for seasonal flu as this has the lowest egg content of any vaccine based on hens' egg and has clinical data to support its use. ${ }^{20}$

Flu vaccines that contain egg should be used with caution and only if other vaccines are not available. A careful assessment should weigh the risks of immunisation against risk of infection with the flu virus. The risk-benefit for each individual will depend on host factors such as underlying chronic illness and current or planned immunosuppression and on viral factors such as the local prevalence and virulence of the seasonal or pandemic virus. In keeping with available safety data, the vaccine should have a stated maximum egg content of $<1.2 \mu \mathrm{g} / \mathrm{ml}(0.6 \mu \mathrm{g}$ per dose $) .{ }^{19}$ The ovalbumin content of the pandemic vaccine Pandemrix (GSK) is not known. We recommend that the maximum egg concentration is added to the "summary of product characteristics" before its licensure.

Adverse events to any flu vaccine should be reported to the Medicines Healthcare Regulatory Agency's Yellow Card scheme (http://yellowcard.mhra.gov.uk).

\section{Is all egg allergy the same?}

Children with positive allergy diagnostics to egg by skin prick testing or specific IgE estimation have the potential for a generalised reaction when presented with allergen via the parenteral route of intramuscular immunisation, even if reactions on oral exposure have been mild. Until better safety data are available we recommend that these individuals are immunised in a facility with staff experienced in treating children with anaphylaxis, most likely secondary care.

We have divided individuals with egg allergy into two risk groups based on our opinion of their potential for anaphylaxis to the vaccine (table 3). ${ }^{24}$ Most children with egg allergy have reactions involving the skin. For the easy application of our recommendations we have simplified the diagnosis of anaphylaxis. ${ }^{25} 26$ If any uncertainty remains about the nature of the allergic 


\section{ADDITIONAL EDUCATIONAL RESOURCES}

\section{For patients}

- NHS Immunisation Information (www.immunisation.nhs. uk)-NHS website giving advice on vaccines, disease, and immunisation in the UK

For healthcare professionals

- Immunisation against infectious disease - "the green book." (www.dh.gov.uk/en/Publichealth/ Healthprotection/Immunisation/Greenbook/ DH_4097254)-Department of Health publication providing advice on immunisation

- BSACl (www.bsaci.org/index.php?option=com clinics\&Itemid=26) - This website of the British Society for Allergy and Clinical Immunology provides information about where the UK NHS and Irish allergy clinics are located, and what services they operate

\section{TIPS FOR NON-SPECIALISTS}

- Celvapan (Baxter), a pandemic A/H1N1 vaccine, and Optiflu (Novartis), a seasonal influenza vaccine are grown in a mammalian cell culture system and are egg-free

- Other flu vaccines are prepared in hens' eggs and may contain small amounts of egg protein

- Individuals with severe egg allergy face a risk of anaphylaxis with flu vaccines that contain egg

reaction they should be considered to be in the higher risk group.

Asthma is a known risk factor for life threatening anaphylaxis, and so we have dealt with children with moderate to severe asthma differently, by including them in the higher risk group irrespective of the severity of their previous reactions to egg. ${ }^{27}$

As an arbitrary cut-off we have used step 3 of the British Thoracic Society/SIGN guidelines, where a long acting $\beta 2$ agonist is added to inhaled corticosteroid therapy. ${ }^{28}$ Children who have uncontrolled asthma should also be included in the higher risk group. We do not recommend that children with acute asthma are immunised; it should be deferred until they have recovered.

We recommend that high risk children should always be immunised in secondary care owing to the availability of advanced paediatric resuscitation facilities. Unlike normal immunisation advice to wait for 20 minutes after the procedure, we advise that higher risk patients should remain on the premises for 60 minutes after immunisation, in keeping with standard allergen immunotherapy practice (where allergic reaction is more commonly encountered) and to refrain from strenuous exercise for 24 hours.

\section{The $A / H 1 N 1$ vaccine}

The A/H1N1 vaccine is expected to consist of two doses three weeks apart. Both doses should be provided in a centre experienced in the management of anaphylaxis. The second dose of the same vaccine can be given in a single $0.5 \mathrm{ml}$ intramuscular injection provided that the first dose has been tolerated.
Contributions: ME-L wrote the article based on previous documents written jointly by all authors. JSAL, NB, and JOW edited and reviewed the article.

Funding: No special funding.

Competing interests: ME-L has received reimbursement to attend scientific meetings from GSK and Wyeth and has an unrestricted educational grant for Sanofi Pasteur MSD.

Provenance and peer review: Not commissioned; externally peer reviewed.

1 Eggesbo M, Botten G, Halvorsen R, Magnus P. The prevalence of allergy to egg: a population-based study in young children. Allergy 2001;56:40311.

2 Howard MK, Kistner O, Barrett PN. Pre-clinical development of cell culture (Vero)-derived H5N1 pandemic vaccines. Biol Chem 2008·389:569-77.

3 Barrett PN, MundtW, Kistner O, Howard MK. Vero cell platform in vaccine production: moving towards cell culture-based viral vaccines. Expert Rev Vaccines 2009;8:607-18.

4 Kursteiner O, Moser C, Lazar H, Durrer P. Inflexal V-the influenza vaccine with the lowest ovalbumin content. Vaccine 2006;24:6632-5.

5 Salisbury D, Ramsay M, Noakes K. Immunisation against infectious disease - the "green book." 4th ed. London: Stationery Office, 2006. www.dh.gov.uk/en/Publichealth/Healthprotection/Immunisation/ Greenbook/DH 4097254

6 Bohlke K, Davis RL, Marcy SM, Braun MM, DeStefano F, Black SB, et al. Risk of anaphylaxis after vaccination of children and adolescents. Pediatrics 2003;112:815-20.

7 Peng MM, Jick H. A population-based study of the incidence, cause, and severity of anaphylaxis in the United Kingdom. Arch Intern Med 2004;164:317-9.

8 Coop CA, Balanon SK, White KM, Whisman BA, Rathkopf MM Anaphylaxis from the influenza virus vaccine. IntArch Allergy Immunol 2008;146(1):85-8

9 Retailliau HF, Curtis AC, Storr G, Caesar G, Eddins DL, Hattwick MA. Illness after influenza vaccination reported through a nationwide surveillance system, 1976-1977. Am JEpidemiol 1980;111:270-8.

10 Pool V, Braun MM, Kelso JM, Mootrey G, Chen RT, Yunginger JW, et al. Prevalence of anti-gelatin IgE antibodies in people with anaphylaxis after measles-mumps rubella vaccine in the United States. Pediatrics 2002;110(6):e71.

11 Bierman CW, Shapiro GG, Pierson WE, Taylor JW, Foy HM, Fox JP. Safety of influenza vaccination in allergic children. J Infect Dis 1977;136(suppl):S652-5.

12 Ratner B, Untracht S. Allergy to virus and rickettsial vaccines. JAMA 1946;132:899-905.

13 MarkC. Large variations in the ovalbumin content in six European influenza vaccines. Pharmeur Sci Notes 2006;2006(1):27-9.

14 Zeiger RS. Current issues with influenza vaccination in egg allergy. JAllergy Clin Immunol 2002;110:834-40.

15 Davies R, Pepys J. Egg allergy, influenza vaccine, and immunoglobulin E antibody. JAllergy Clin Immunol 1976;57:373-83.

16 Miller JR, Orgel HA, Meltzer EO. The safety of egg-containing vaccines for egg-allergic patients. J Allergy Clin Immunol 1983;71:568-73.

17 Murphy KR, Strunk RC. Safe administration of influenza vaccine in asthmatic children hypersensitive to egg proteins.J Pediatr 1985;106:931-3.

18 Anolik R, Spiegel W, Posner M, Jakabovics E. Influenza vaccine testing in egg sensitive patients. Ann Allergy 1992;68(1):69.

19 James JM, Zeiger RS, Lester MR, Fasano MB, Gern JE, Mansfield LE, et al. Safe administration of influenza vaccine to patients with egg allergy. J Pediatr 1998;133:624-8

20 Esposito S, Gasparini C, Martelli A, Zenga A, Tremolati E, Varin E, et al. Safe administration of an inactivated virosomal adjuvanted influenza vaccine in asthmatic children with egg allergy. Vaccine 2008;26:4664-8.

21 Piquer-Gibert M, Plaza-Martin A, Martorell-Aragones A, Ferre-Ybarz L, Echeverria-Zudaire L, Bone-Calvo J et al. Recommendations for administering the triple viral vaccine and antiinfluenza vaccine in patients with egg allergy. Allergol Immunopathol (Madr) 2007;35:209-12.

22 Committee on Infectious Diseases, American Academy of Pediatrics. Active immunization. In: Pickering LK, Baker Cl, Long SS, McMillan JA eds. Red book: report of the committee of infectious diseases. 27th ed. Elk Grove Village, IL: American Academy of Pediatrics, 2006:9-54.

23 Nasser S, Brathwaite N. Swine flu vaccination in patients with egg allergy. Clin Exp Allergy 2009;39:1288-90.

24 Brown SG. Clinical features and severity grading of anaphylaxis. J Allergy Clin Immunol 2004;114:371-6.

25 Sampson HA, Munoz-Furlong A, Campbell RL, Adkinson NFJr, BockSA, Branum A, et al. Second symposium on the definition and management of anaphylaxis: summary report-second National Institute of Allergy and Infectious Disease/Food Allergy and Anaphylaxis Network symposium.J Allergy Clin Immunol 2006;117:391-7.

26 Ruggeberg JU, Gold MS, Bayas JM, Blum MD, Bonhoeffer J, Friedlander $\mathrm{S}$, et al. Anaphylaxis: case definition and guidelines for data collection, analysis, and presentation of immunization safety data. Vaccine 2007;25:5675-84.

27 Colver AF, Nevantaus H, Macdougall CF, Cant AJ. Severe food-allergic reactions in children across the UK and Ireland, 1998-2000. Acta Paediatr 2005;94:689-95.

28 British Thoracic Society Scottish Intercollegiate Guidelines Network. British guideline on the management of asthma. Thorax 2008;63(suppl 4):1-121.

Accepted: 6 September 2009 